Sakarya Üniversitesi İlahiyat Fakültesi Dergisi

Journal of Sakarya University Faculty of Theology

ISSN: 2146-9806 | e-ISSN: 1304-6535

Cilt/Volume: 21, Sayı/Issue: 40, Y11/Year: 2019 (Aralık/December)

\title{
Kanser Hastalarında Yaşam Kalitesini Etkileyen Din ve Maneviyat Üzerine Teorik Yaklaşımlar
}

Theoretical Approaches on Religion and Spirituality Affecting the Quality of Life in the Cancer Patients

\author{
Ahmet Albayrak \\ Doç. Dr., Bursa Uludağ Üniversitesi, İlahiyat Fakültesi, Din Psikolojisi Bilim Dalı - Assoc. \\ Prof. Dr., Uludağ University, Faculty of Theology, Department of Psychology of Religion. \\ ahmetalbayrak1@gmail.com - https://orcid.org/0000-0001-8293-9940

\section{İbrahim Yıldırım} \\ Uzm. Dr., Medicana Bursa Hastanesi, Radyasyon Onkolojisi Bölümü - Ph.D., \\ Medicana Bursa Hospital, Department of Radiation Oncology. \\ driyildirim@hotmail.com - https://orcid.org/0000-0003-4867-8315

\section{Emine Kurt} \\ Doktora Öğrencisi, Uludağ Üniversitesi, Sosyal Bilimler Enstitüsü, Din Psikolojisi \\ Bilim Dalı - Ph.D. Candidate, Uludağ University, Institute of Social Sciences, \\ Department of Psychology of Religion. \\ fekurt@gmail.com - https://orcid.org/0000-0002-8677-5864

\section{Makale Bilgisi - Article Information}

Makale Türü/Article Type: Araştırma Makalesi/ Research Article

Geliş Tarihi/Date Received: 15/08/2019

Kabul Tarihi/Date Accepted: 04/12/2019

Yayın Tarihi/Date Published: 15/12/2019

Atıf/Citation: Albayrak, Ahmet - Yıldırım, İbrahim - Kurt, Emine. "Kanser Hastalarında Yaşam Kalitesini Etkileyen Din ve Maneviyat Üzerine Teorik Yaklaşımlar". Sakarya Üniversitesi İlahiyat Fakültesi Dergisi 21/40 (2019): 349-376. https://doi.org/10.17335/sakaifd.605552

İntihal: Bu makale, iThenticate yazılımı ile taranmış ve intihal tespit edilmemiştir. Plagiarism: This article has been scanned by iThenticate and no plagiarism detected.

Copyright () Published by Sakarya Üniversitesi İlahiyat Fakültesi - Sakarya University Faculty of Theology, Sakarya/Turkey. 


\title{
Kanser Hastalarında Yaşam Kalitesini Etkileyen Din ve Maneviyat Üzerine Teorik Yaklaşımlar
}

\section{Öz}

Bu makalenin amacı, kanser hastalarında yaşam kalitesi ve din/maneviyat (D/M) arasındaki ilişkileri ortaya koymak, yaşam kalitesi üzerinde D/M'nin hangi yollarla etkili olabileceğini tartışmaktır. Bu amaca yönelik olarak konu, ilgili literatür bağlamında teorik bir yaklaşımla ele alınmıştır. Yaşam kalitesi, bireyin yaşamdan aldığı doyum, mutluluk ve memnuniyet düzeyiyle ilişkili çok yönlü ve geniş bir kavramdır. Kanser hastalarında yaşam kalitesi, fiziksel, emosyonel, sosyal, ekonomik ve spiritüel boyutlarıyla bireysel iyilik halinin öznel bir ifadesi olarak kabul edilir. Kanserde yaşam kalitesini etkileyen çok sayıda fiziksel ve psikososyal değişken vardır. Yakın zamanlı çalışmalar, kanser hastalarında dini ve manevi kaynakların, tanı ve tedaviye ilişkin sorunların üstesinden gelmeye ve daha iyi bir yaşam kalitesine katkı sağlamaya destek olduğunu göstermektedir. Onkolojide güncel yaklaşım, daha uzun ve daha iyi bir yaşam kalitesi için gerekli tıbbi tedavinin yanında bireysel özellik ve gereksinimleri dikkate alarak hastalara rehabilitasyon, bakım ve destek hizmetlerinin sunulmasıdır. Bu kapsamda kanser hastalarında dini ve manevi bakım ve desteğin, yaşam kalitesi üzerinde olumlu yönde etkileri olacağı düşünülmektedir.

Anahtar Kelimeler: Din Eğitimi, Kanser, Onkoloji, Yaşam kalitesi, Din, Maneviyat.

\section{Theoretical Approaches on Religion and Spirituality Affecting the Quality of Life in the Cancer Patients}

\begin{abstract}
The aim of this article is to demonstrate the relationship between quality of life and religion and spirituality (R/S) in cancer patients and to discuss the ways in which R/S can influence life quality. For this purpose, the subject was discussed with a theoretical approach in the context of related literature. Quality of life is a versatile and broad concept related to the level of satisfaction, happiness and satisfaction that an individual receives from life. The quality of life in cancer patients is regarded as a subjective statement of individual well-being, with physical, emotional, social, economic and spiritual dimensions. Based on the literature on the subject, it has been shown that R/S resources in cancer patients help to overcome problems related to diagnosis and treatment and to contribute to a better quality of life. The current approach in the oncology is to provide rehabilitation, care, and support services for patients, taking into account individual characteristics and needs, as well as medical treatment for longer and better quality of life. In this context, it is thought that R/S care and support in cancer patients will have positive effects on quality of life.
\end{abstract}

Keywords: Religious Education, Cancer, Oncology, Quality of life, Religion, Spirituality.

\section{Giriş}

Kanser; her geçen gün artan, yaşamı çok yönlü olarak tehdit eden, maddi ve manevi kayıplara neden olan günümüzün en önemli sağlık problemlerinden birisidir. En son yayınlanan kanser istatistiklerine göre dünya genelinde ölüm nedenleri arasında ilk sırayı kanser almaktadır ve 14,1 milyon yeni kanser vakası tespit edilmiştir. ${ }^{1} \mathrm{Bu}$ sayısal artışa göre 2030 yılında yıllık 22 milyon yeni vakanın ortaya çıkacağı tahmin edilmektedir. ${ }^{2}$

1 WHO, "Cancer today", erişim: 26 Haziran 2018, http://gco.iarc.fr/today/home .

2 Türkiye Kanser İstatistikleri (Ankara: T. C. Sağlık Bakanlığı Türkiye Halk Sağlığı Kurumu, 2017), 1. 
Kanser, tedavisi ve yaşantısı ile bireyi çok yönlü olarak etkileyen zorlu bir süreçtir. Hastalığın ağır bir seyirde ilerlemesi, tedavinin uzun sürmesi ve çok sayıda yan etkilerinin olması vb. sorunlar, fiziksel performansı ve günlük yaşam aktivitelerini azaltarak yaşam kalitesinin düşmesine, genel iyilik halinin ve psiko-sosyal düzeyde hayatlarının olumsuz yönde etkilenmesine neden olur.

Kanser tanısı; ölümü ve şiddetli acıyı çağrıştıran, varoluşsal kaygıları, sorgulamaları beraberinde getiren bir hastalıktır. Kansere karşı gösterilen tepkiler ve kansere yüklenilen anlamlar kişinin kendi anlamlandırma sistemleri, değerleri ve inançları ile yakından ilişkilidir. ${ }^{3}$ Bu ilişkiler ağının, kanserle baş etme, fiziksel ve ruhsal sağlık, hastalığa uyum ve yaşam kalitesi üzerinde de etkisi olduğu söylenebilir. Literatür, hastaların yaşam kalitesi düzeyinin artmasıyla hastalığa uyum, mücadele ve tedaviye yanıt arasında olumlu ilişkiler olduğunu göstermektedir. ${ }^{4}$

Kanser hastalarında yaşam kalitesi, çok boyutlu olarak ele alınan önemli bir kavramdır. Sağlıkta yaşam kalitesi, genel olarak fiziksel, psikolojik ve sosyal boyutlarda değerlendirilmiştir. Ancak yapılan çalışmalar, kavramın sanıldığından çok daha kompleks ve etkileşim alanlarının daha geniş olduğunu ortaya koymuştur. Yaşam kalitesi ve boyutları üzerine yapılan yeni çalışmalar din ve maneviyatın, yaşam kalitesinin önemli bir bileşeni olduğunu göstermektedir. ${ }^{5}$ Din ve maneviyat, günümüz sağlık araştırmalarında popüleritesi gittikçe artan iki kavram olarak karşımıza çıkmaktadır. Fakat bu iki kavram üzerinde ortak bir tanım ve uzlaşı yoktur. Genel olarak din, "kurumsallaşmış bir olgu" , maneviyat ise "bireysel bir yönelim" olarak değerlendirilmektedir. ${ }^{6}$ Diğer taraftan tartışmalar, bu iki kavramın kutuplaştırılması ile sınırlı olmayıp tartışmalarda kapsayıcılık ve genişlik konusunda da ayrışmalar vardır. Buna göre bir kısım görüşler din olgusunun maneviyatı kapsadı̆̆ını, bir kısmı

3 Saliha Hallaç - Fatma Öz, "Genital Kanser Tanı Sürecinde Varoluşsal Kaygı", Psikiyatride Güncel Yaklaşımlar 3/4 (2011): 595-610.

4 Nalini Tarakeshwar v.dğr., "Religious Coping is Associated with the Quality of Life of Patients with Advanced Cancer", Journal of Palliative Medicine 9/3 (2006): 646-657; Tracy A. Balboni v.dğr., "Religiousness and Spiritual Support Among Advanced Cancer Patients and Associations With End-of-Life Treatment Preferences and Quality of Life", Journal of Clinical Oncology 25/5 (2007): 555-560.

5 University of Toronto, "Quality of Life Research Unit: Home Page", erişim: 26 Haziran 2018, http://sites.utoronto.ca/qol/qol model.htm ; World Health Organization, "WHOQOL-SRPB : scoring and coding for the WHOQOL SRPB field-test insturment: users manual", 2002.

6 Doug Oman - Carl E. Thoresen, "Din ve Maneviyat Sağlığı Etkiler mi?", Din ve Maneviyat Psikolojisi: Yeni Yaklaşımlar ve Uygulama Alanları, ed. Raymond F. Paloutzian - Crystal L. Park, ed. İhsan Çapcıoğlu - Ali Ayten, trc. Özer Çetin (Ankara: Phoenix Yayınevi, 2013), 302. 
ise maneviyatın, dini de kapsayan daha geniş bir kavram olduğunu savunmaktadır. ${ }^{7}$

Sağlık araştırmalarında kavramsal olarak din ve maneviyat, genel olarak kutuplaştırıcı tanımlar çerçevesinde ele alınır ancak operasyonel tanımlardaki farklılıklara da dikkat çekilerek şüpheli bir yaklaşım sergilenir. ${ }^{8}$ Örneğin, dini inancı olmayan hastalar, spiritüel gereksinimlerini varoluşsal ve hümanistik çerçevede, dini inancı olan hastalar ise dini referanslar çerçevesinde yorumlayabilmektedir. ${ }^{9}$ Yine bazı çalışmalarda operasyonel olarak maneviyat altında dini tutum ve yönelime; din adı altında ise maneviyata ilişkin unsurlara yer verilmektedir. ${ }^{10}$ Bunlar iki kavram arasındaki akışkanlığın göstergesi olarak kabul edilebilir. Koenig; sağlık araştırmalarında dini yönelime yer vermeyen maneviyat ölçümlerinin çelişkili ve yorumlanamayan sonuçlar ortaya koyduğunu ancak dini göstergelere yer veren metodolojik olarak titizlikle hazırlanmış çalışmaların anlamlı ve yorumlanabilir bulgular verdiğini belirtir. ${ }^{11}$ Din, maneviyat ve sağlık ilişkisini konu edinen literatürde genel eğilim, din ve maneviyat hakkındaki kavramsal tartışmaların çalışma kapsamı dışında tutulmasıdır. İlgili çalışmalarda her iki kavramın geniş bir perspektifle ele alınmasının tercih edildiği hatta bazı çalışmalarda bu iki kavramın birbirinin yerine de kullanıldığı görülmektedir. ${ }^{12}$ Bu çalışmada da "din ve maneviyat"a ilişkin tartışmalar, çalışmanın amaç ve kapsamının dışında tutulmuştur. Mevcut literatür dikkate alınarak "din ve maneviyat" kavramlarına geniş bir perspektiften yaklaşılmış ve makale boyunca bu kavramlar yerine D/M kullanımı tercih edilmiştir.

7 Brian J Zinnbauer - Kenneth Pargament, "Dindarlık ve Maneviyat", Din ve Maneviyat Psikolojisi: Temel Yaklaşımlar ve İlgi Alanları, ed. Raymond F. Paloutzian - Crystal L. Park, ed. İhsan Çapcıoğlu - Ali Ayten, trc. Sevdenur Düzgüner (Ankara: Phoenix Yayınevi, 2013), 61-102.

8 Crystal L. Park v.dğr., "Advancing our understanding of religion and spirituality in the context of behavioral medicine", Journal of Behavioral Medicine 40/1 (2017): 39-51; Harold G Koenig, "Religion, spirituality, and Health: a Review and Update", Advances In Mind-Body Medicine 29/3 (2015): 19-26.

9 Arndt Büssing - Harold G. Koenig, "Spiritual Needs of Patients with Chronic Diseases", Religions 1/1 (2010): 18-27.

10 Christian Zwingmann v.dğr., "Religious Commitment, Religious Coping and Anxiety: A Study in German Patients With Breast Cancer", European Journal of Cancer Care 17 (2008): 361367; Melike Boztilki - Elif Ardıç, "Maneviyat ve Sağlık", Journal of Academic Research in Nursing, Ek Sayı (2017): 39-45; Nalika Unantenne v.dğr., "The Strength to Cope: Spirituality and Faith in Chronic Disease", Journal of Religion and Health 52/4 (2013): 1147; Arndt Büssing Harold G. Koenig, "Spiritual Needs of Patients with Chronic Diseases", Religions 1/1 (2010): 18-27; Andreas Hoff v.dğr., "Religion and Reduced cancer risk - What is the explanation? A review", European Journal of Cancer 44/17 (2008): 2573-2579.

11 Koenig, "Religion, Spirituality, and Health", 21.

12 Koenig, "Religion, Spirituality, and Health"; Park v.dğr., "Advancing Our Understanding of Religion and Spirituality in The Context of Behavioral Medicine". 
Bu makalenin amacı da D/M'nin, yaşam kalitesinin bütünüyle ve alt boyutları (fizyolojik, psikolojik, sosyal, spiritüel vb.) ile olan ilişkilerinin değerlendirilmesi ve tartışılması olarak belirlenmiştir. Bu amaç çerçevesinde ilgili literatür taraması yapılmış ve konu, teorik bir zeminde incelenmiştir. Ancak kanser hastalarında D/M ile yaşam kalitesi arasındaki ilişkilerin sanıldığından daha geniş ve karmaşık olması konunun sınırlandırılarak din psikolojisinde sıklıkla kullanılan dua etme, çaresizlik, bağlanma ihtiyacı, varoluşsal kayg1lar, anlam arayışı, ölüm korkusu, sıkıntı ve güvenlik ihtiyacı vb. ${ }^{13}$ dini yönelim faktörleri çerçevesinde tartışılmasını gerekli kılmıştır.

\section{Yaşam Kalitesi Kavramının Tanımlanması}

Yaşam kalitesi, bireysel ve toplumsal refahtan, çevre koşullarının kalitesine ve ekolojik yapıların yaşanabilirliğine dek birçok alanda kullanılan ve çok boyutlu değişkenleri içeren önemli bir kavramdır. 1960'lı yıllardan önce sosyoloji ve ekonomi bilimlerinde, sonraki yıllarda ise psikoloji ve tıp alanında bu kavrama ilgi gösterilmeye başlanmıştır. ${ }^{14}$ Yaşam kalitesi kavramı ilk kez 1939'da Thorndike tarafından kullanılmış ve "sosyal çevrenin bireyde yansıyan tepkisi" olarak tanımlanmıştır. ${ }^{15}$

Yaşam kalitesi kavramına farklı bilimsel disiplinler, farklı tanım ve yorumlamalar getirmiştir. Dolayısıyla bu kavram için ortak bir tanımdan ya da parametreden söz etmek mümkün değildir. Melson ${ }^{16}$ yaşam kalitesini geleceğe ilişkin umut, yeterli gıda, giyecek, barınma koşulları, gelir düzeyi, işle ilgili beklentilerin karşılanması, anne ve çocuk sağlı̆̆ı, aile ve toplumsal refahın sağlanması olarak görmektedir.

Çeşitli tanımlamalarda yaşam kalitesinin mutluluk, uyum, doyum, memnuniyet gibi kavramlarla ifade edildiği görülmektedir. ${ }^{17}$ Patrick ve Erichson ${ }^{18}$ yaşam kalitesini, ölüm ve yaşam süresi, özürlülük, fonksiyonel durum, sosyal, psikolojik veya fiziksel sağlı̆̆ın algılanması ve sosyo-kültürel dezavantajları içeren temel bir kavram olarak tanımlamışlardır. Başka bir çalışmada ${ }^{19}$,

13 Hayati Hökelekli, Din Psikolojisine Giriş (İstanbul: Dem Yayınları, 2010), 104.

14 Sevban Arslan - Nurgül Bölükbaş, "Kanserli Hastalarda Yaşam Kalitesinin Değerlendirilmesi", Atatürk Üniversitesi Hemşirelik Yüksekokulu Dergisi 6/3 (2003): 38-47.

15 Asiye Akyol, "Yaşam Kalitesinin Hemşirelik Yönünden Önemi”, Ege Üniversitesi Hemşirelik Yüksekokulu Dergisi 9/3 (1993): 71-75.

16 F. Gail Melson, Family and Environment: an Ecosystem Perspektive (Minneapolis: Burgess, 1980); akt. Emine Özmete, "Aile Yaşam Kalitesi Dinamikleri: Aile İletişimi, Ebeveyn Sorumlulukları, Duygusal Refah, Fiziksel/Materyal Refahın Algılanması", Uluslararası Sosyal Araştırmalar Dergisi 3/11 (2010): 455.

17 Arslan - Bölükbaş, “Kanserli Hastalarda Yaşam Kalitesinin Değerlendirilmesi”.

18 D. L. Patrick - P. Erichson, Health Status and Health Policy (New York: Oxford University Press, 1993).

19 JC de Haes - FCE Knippenherg, "The Quality of Life and Survival: The Role of Multidimensionel Symptom Assessment", Cancer 83 (1993): 173-179. 
“kişilerin yaşamlarını değerli buldukları şekilde sürdürme yetileri” olarak; Maeland ${ }^{20}$ tarafından ise "mutluluk, doyum, gereksinim duyulan memnuniyet ve kendini gerçekleştirme" kavramları ile açıklanmıştır. ${ }^{21}$ Ayrıca "bireyin sahip olduğu kendine saygı ve yaşam amacı" 22 olarak da ele alınmıştır.

Hörnquist ${ }^{23}$ yaşam kalitesini "fiziksel, psikolojik, sosyal aktivite, maddi ve yapısal alanda tatmin olma ihtiyacının derecesi"; Cella ${ }^{24}$ ise fiziksel, fonksiyonel, emosyonel ve sosyal faktörlerin kombinasyonundan oluşan bir iyilik hali olarak tanımlamıştır. Szalai'ne göre de yaşam kalitesi, bireyin yaşamının iyi ve tatminkâr özelliklerinin genel bir değerlendirmesidir. ${ }^{25}$ Campell ve arkadaşları, yaşam kalitesinin en iyi belirleyicisi olarak "yaşam doyumu" kavramı ile ifade edilebileceğini belirtmişlerdir. ${ }^{26}$

Yaşam doyumu ve yaşam kalitesi kavramlarının birbirlerinden farklı oldukları fakat yaşam doyumunun, yaşam kalitesinin içerisinde yer alan bir kavram olduğu belirtilmektedir. ${ }^{27}$ Yaşam doyumu, "bir insanın istedikleri ile elde ettiklerinin karşılaştırılması ile oluşan sonuç" olup bireyin tüm yaşam süreci içinde yer alan ve psikolojik durumuna ilişkin sübjektif bir kavramdır. ${ }^{28}$ Yaşam kalitesi bir iş ve hobilere sahip olmak ya da sosyal bir çevrede bulunmaktan öte "kişisel doyum" u ifade eden ve kişinin hayat görüşü ve değer yargıları ile bağlantılı bir anlam içerir. Yaşam kalitesini etkileyen bireysel iyilik hali ise öznel bir durum olup bireyden bireye, şartlara ve ruh haline göre değişim gösterebilir. Bireysel iyilik halinin en önemli belirleyicilerinden biri olan yaşam alanı, bir kişi için işinden aldı̆̆ı doyum iken bir başkası için yakınlarıyla kurduğu ilişkidir. Âni hastalıklar, haksızlığa uğramak, sevmek,

20 A. Hutchinson v.dğr., Health Outcome Measures in Primary and Out-Patient Care (Amsterdam: Harwood Academic Publishers, 1996), 189.

21 Aysun Perim, Trakya Üniversitesi Ĕ̆itim, Araştırma ve Uygulama Hastanesi'nde Çalışan Hemşirelerin Kaliteli Yaşam Algısının Belirlenmesi (Yüksek Lisans Tezi, Trakya Üniversitesi, 2007), 10.

22 F. M. Lewis, "Experienced Personal Control and Quality of Life in Late-Stage Cancer Patients", Nursing Research 31/2 (1982): 113-119.

23 J. O. Hörnquist, "Quality of Life: Concept and Assessment”, Scandinavian Journal of Social Medicine 18/1 (1990): 69-79.

24 David Cella, "Quality of Life: The Concept", Journal of Palliative Care 8/13 (1992): 8-13.

25 Şule Arslan - Yeşim Gökçe Kutsal, "Geriatride Yaşam Kalitesinin Değerlendirimi”, Geriatri 2/4 (1999): 174.

26 Angus Campbell v.dğr., The Quality of American Life: Perceptions, Evaluations, and Satisfactions, 1st US-1st Printing edition (New York: Russell Sage Foundation, 1976); G. V. Padilla v.dğr., “Nursing Research into Quality of Life", Quality of Life Research 1/5 (1992): 341-348; Hutchinson v.dğr., Health Outcome Measures in Primary and Out-Patient Care.

27 Aylin Görgün-Baran, "Yaşlılıkta Sosyalizasyon ve Yaşam Kalitesi", Yaşlı Sorunları Araştırma Dergisi 2 (2008): 86-97.

28 Nurgün Oktik - Ünal Bozyer, Huzurevinde Yaşam Ve Yaşam Kalitesi: Muğla Örneği (Muğla: Muğla Üniversitesi, 2004), 61-79; Görgün-Baran, “Yaşlılıkta Sosyalizasyon ve Yaşam Kalitesi". 
saygı görmek vb. durumlar, bireysel iyilik halinde değişime neden olabilmektedir. ${ }^{29}$

Yaşam kalitesi geçmişten bugüne tıbbi düşünceleri ve eylemleri de etkileyerek mutluluk, yaşamın anlamı, kendini iyi hissetme, rahat yaşam sürme, yaşam amacı, yaşama şansı ve hayatın değeri gibi kavramlar çerçevesinde tartışılmış ve yorumlanmıştır. ${ }^{30}$

Dünya Sağlık Örgütü'nün (DSÖ) 1946 yılında sağlığı, “yalnızca hastalık ve sakatlığın olmayışı değil, fiziksel, ruhsal ve sosyal yönden tam iyilik hali" 31 olarak tanımlamasının ardından "yaşam kalitesi" kavramına ilginin arttığı ancak tıp literatüründe terim olarak ilk defa Long'un 1960 yılında yayınlanan "On the Quantity and Quality of Life" 32 başlıklı makalesinde geçtiği görülmektedir. Bu tarihten itibaren sağlıkta "yaşam kalitesi" kavramı ile öne çıkan çok sayıda çalışma yayınlanmıştır.

Dünya Sağlık Örgütü, yaşam kalitesini, "bireylerin içinde yaşadığ1 kültür ve değer sistemleri bağlamında hedefleri, beklentileri, standartları ve endişeleri açısından yaşamdaki durumlarına ilişkin bireysel algıları" olarak tanımlamaktadır. Yaşam kalitesi bireyin fiziksel sağlığı, psikolojik durumu, bağımsızlık/serbestlik düzeyi, sosyal ilişkileri, bireysel inançları ve çevresel ilişkilerinden çok yönlü bir şekilde etkilenen geniş kapsamlı bir kavram olarak görülmektedir. 33

Sağlıkta "yaşam kalitesi" kavramı yaygın kabule göre "hastalığın ve tedavisinin hasta üzerindeki etkilerinin yine hasta açısından değerlendirilmesi" olarak tanımlanabilir. ${ }^{34}$ Dolayısıyla sağlık alanında yaşam kalitesi, sağlık çalışanlarının hastayla ilgili fizyolojik fonksiyonlarını değerlendirmekten çok hastanın algılamalarını, hastalık ve tedavisiyle ilgili yaşantılarını ifade eder. Buna göre sağlıkta yaşam kalitesi, bireyin içinde bulunduğu duruma emosyonel (duygusal) yanıtı, hastalığın bireyin sosyal, mesleki ve aile yaşantısı üzerindeki etkisi, bireysel iyilik hali, kişinin beklentileri ve gerçek durumu arasındaki karşılaştırmaları ve farkları, fiziksel, sosyal ve emosyonel fonksiyonların doyumu ve ihtiyaçlarını karşılamada bireysel yeterlilik gibi birçok boyutta değerlendirilmektedir. ${ }^{35}$

29 Mehmet Şerif Top v.dğr., "Psikiyatride Yaşam Kalitesi”, Düşünen Adam 16/1 (2003): 20.

30 Zehra Edisan - Funda Kadığlu, "Yaşam Kalitesi Kavramının Antik Dönemdeki Öncülleri”, Lokman Hekim Journal 3/3 (2013): 1-4.

31 WHO, "The Constitution of the WHO" (WHO Chronicle, 1947), 29; akt. Talha Müezzinoğlu, "Yaşam Kalitesi", Üroonkoloji Bülteni, 1 (2005): 25-29.

32 P. H. Long, “On the Quantity and Quality of Life", Medieval Times 88 (1960): 613-619; akt. Müezzinoğlu, "Yaşam Kalitesi", 25.

33 WHO, "WHOQOL: Measuring Quality of Life", 1997, 1, erişim: 26.06.2018, https://www.who.int/healthinfo/survey/whoqol-qualityoflife/en/ .

34 Müezzinoğlu, "Yaşam Kalitesi”, 26.

35 Mukadder Mollaoğlu, "Kronik Hastalıklarda Yaşam Kalitesi ve Hemşirelik", 2. Sağlıkta Yaşam Kalitesi Kongresi Kongre Özet Kitabı (İzmir: Meta Basım, 2007), 9. 
"Yaşam kalitesi" ve "sağlıkta yaşam kalitesi", bir görüşe göre birbirinden ayrılarak incelenmeli, diğer bir görüşe göre ise aslında yaşam kalitesinin tüm boyutları, sağlıkta yaşam kalitesinin de belirleyici unsurlarıdır ve bu iki kavramı birbirinden ayırmak imkânsızdır. Örneğin; gelir düzeyi, sosyal imkânlar, politik ortam, çevre koşulları ve bireysel inançların genel yaşam kalitesinin içinde değerlendirildiği ancak bunların sağlıkta yaşam kalitesinden ayrı düşünülmesinin bir yanılgı olacağı ifade edilmiştir. Çünkü bu unsurların çoğunun aynı zamanda sağlık sorunlarının da temel belirleyicisi olarak rol aldı̆̆1 görülmektedir. ${ }^{36}$

\section{Kanser Hastalarında Yaşam Kalitesi}

Onkoloji alanındaki ilerlemelere rağmen ölümü ve acıyı çağrıştırması sebebiyle en fazla korku, endişe ve ümitsizlik oluşturan hastalık, kanserdir. Kanser hastaları, bir taraftan hastalığın fiziksel ve ruhsal semptomları ile başa çıkmaya, diğer taraftan da günlük yaşam aktivitelerini sürdürmeye çalışmaktadırlar. Bu zorlu süreçte kanser hastalığının aile, sosyal yaşam, eğitim, çalışma ve mesleki yaşantı gibi hayatın birçok alanında kısıtlamalar oluşturduğu, yaşam kalitesini fiziksel, sosyal, emosyonel ve maddi boyutları ile etkilediği belirlenmiştir. Dolayısıyla kanser, yalnız bireysel bir hastalık deneyimi olmayıp aile, tedavi ekibi ve sosyal çevrenin de katıldığ

Kanser tanısı almanın, tedavinin uzun sürmesinin ve tedaviye bağlı olumsuzlukların devam etmesinin belirsizlik ve ümitsizliğe yol açtığı, karamsarlık, anksiyete ve depresyona neden olduğu görülmektedir. Tedavi sürecinde karşılaşılan fiziksel ve psikolojik güçlüklerin de etkisiyle kanser hastalarında yaşam kalitesi düşmektedir. Özellikle kemoterapi gibi tüm sistemleri etkileyen ve bireyin günlük yaşamını zorlaştıracak düzeyde yan etkileri olan kanser tedavilerinin yaşam kalitesi üzerinde belirgin etkileri olmaktadır. ${ }^{38}$

Kemoterapiye bağlı olarak hastalarda anemi, enfeksiyon, yorgunluk, mide-bağırsak şikayetleri, bulantı, kusma vb. şikayetler ortaya çıkmaktadır. Kemoterapinin yan etkilerinden ya da hastalığın kontrol edilemeyen semptomlarından dolayı kanser hastalarında depresyon görülme sıklığının yüksek olduğu bildirilmiştir. Kanser hastalarında tedaviye ve semptomlara bağlı ola-

36 Müezzinoğlu, "Yaşam Kalitesi", 27.

37 Füsun Afşar, "Sandalye Masajı Kanserli Hastalara Bakım Veren Aile Üyelerinin Yaşam Kalitesine Katkı Verebilir mi?", 3. Ulusal Sağlıkta Yaşam Kalitesi Kongresi Bildiri ve Sunum Kitabı (İzmir: SAYKAD, 2010), 38.

38 Emine Kurt, Meme Kanserli Hastalarda A ğrı ve Uzuv Kaybına (mastektomi) Bă̆lı Depresyon Düzeylerinin Yaşam Kalitesi ve Dindarlık ile İlişkisi (Yüksek Lisans Tezi, Uludağ Üniversitesi, 2015), 86; Nalan G. Beser - Fatma Öz, "Kemoterapi Alan Lenfomalı Hastaların Anksiyete-Depresyon Düzeyleri ve Yaşam Kalitesi", Cumhuriyet Üniversitesi Hemşirelik Yüksekokulu Dergisi 7/1 (2003): 47-58. 
rak ortaya çıkan fonksiyonel yetersizlik, psikolojik problemler, rol performansında düşüklük gibi faktörler, hastaların günlük aktivitelerinin kısıtlanmasına, sosyal çevreden izolasyona, iş performansında düşüklüğe neden olarak yaşam kalitesini azaltır. ${ }^{39}$

Padilla ve arkadaşları, kanser hastalarının kronik ağrısı olduğunu ve ağr1nın fiziksel, psikolojik ve kişiler arası iyilik hali olmak üzere yaşamın üç önemli boyutunda etkili olduğunu tespit etmişlerdir. ${ }^{40}$ Ağrı, kanser hastaları için fiziksel, ruhsal ve sosyal boyutta önemli bir problem olup tüm kanser hastalarının yarısında ve ileri evre kanser hastalarının \%90'ından fazlasında görülen bir semptomdur. Devam eden ve dindirilemeyen kanser ağrısının, yaşamın hemen hemen tüm alanlarında zararlı ve olumsuz etkisi olduğu söylenebilir. Ağrı, kanser hastalarında depresyonun yanı sıra anksiyete ve duygusal sıkıntıya neden olur ve bireylerin iyilik halini etkiler. Aynı zamanda ağrı, bireylerin ailevi, sosyal ve mesleki rolleri ile fonksiyonel ve ruhsal fonksiyonlarını kısıtlayarak yaşam kalitesini düşürür. ${ }^{41}$

Kanser hastalarında yaşam kalitesini düşüren önemli faktörlerden birisi de yorgunluktur. Yorgunluk, kansere veya uygulanan tedaviye bağlı olarak gelişen, kişinin geçmişteki aktivitesinden bağımsız olan ve günlük fonksiyonlarını etkileyen sübjektif bir bitkinlik ve tükenmişlik hissi olarak değerlendirilebilir. Tüm kanser hastalarının \%78-96'sında ve radyoterapi uygulanan olguların ise \%75-100'ünde işınlanan bölgeye göre farklı şiddetlerde yorgunluk yaşandı̆̆ı belirlenmiştir. ${ }^{42}$

Kanser, aynı zamanda bireylerin beden imajında da önemli değişimlere yol açan bir hastalıktır. Özellikle, kanserde etkin olarak kullanılan kemoterapi tedavisinde saç dökülmesi, kilo kaybı, bulantı, kusma gibi yan etkilerin bireylerin beden imajını olumsuz yönde etkilediği ve yaşam kalitesini düşürdüğü

39 Beser - Öz, "Kemoterapi Alan Lenfomalı Hastaların Anksiyete-Depresyon Düzeyleri ve Yaşam Kalitesi".

40 G. V. Padilla v.dğr., "Defining the Content Domain of Quality of Life for Cancer Patients with Pain", Cancer Nursing 13/2 (1990): 108-115.

41 Yasemin Kuzeyli Yıldırım v.dğr., “Kanser Ağrısı ve Yaşam Kalitesine Etkisi”, A 17-22; Thomas E Elliott v.dğr., "Chronic Pain, Depression, and Quality of Life: Correlations And Predictive Value of The SF-36", Pain Medicine (Malden, Mass.) 4/4 (2003): 331-339.

42 Diclehan Ünsal v.dğr., "Postmastektomi Radyoterapi Uygulanan Meme Kanserli Olgularda Gelişen Yorgunluğun Derecesi, Serum Sitokin ve Leptin Düzeyleri ile İlişkisi: Prospektif Değerlendirme", Türk Onkoloji Dergisi 22/1 (2007): 1-12. 
belirlenmiştir. ${ }^{43}$ Meme kanseri kadınlarda, özellikle mastektomi (meme kanserinde, "memenin cerrahi olarak kısmen veya tamamen çıkarılması işlemi") ${ }^{44}$ sonrası fiziksel, ruhsal ve cinsel yaşamda önemli problemlerin ortaya çıktığı görülmüştür. Yapılan araştırmalarda total mastektominin beden algısını ve eş uyumunu olumsuz yönde etkilediği, benlik saygısında azalma, uyum bozukluğu, major depresyon, anksiyete gibi sorunlara neden olduğu tespit edilmiştir. ${ }^{45}$

Yapılan çalışmalarda kanser ve kronik rahatsızlıkların, hastaların sağlığı, bağımsızlığı, kontrol gücü, mahremiyeti, sosyal statü ve rolleri, kendine güven duygusu ve geleceği planlama gücü üzerinde olumsuz etkilere neden olduğu görülmektedir. Kanser ve birçok kronik hastalıkta, bireylerin günlük yaşam aktivitelerinin kısıtlanması, güçsüzlük, hastalık semptomları, tedavi süresinin uzun olması, hastaneye tekrarlı yatışlar ya da sık kontroller, tıbbi bir cihaza bağlı olunması, günde birkaç defa ilaç alınması, alınan ilaçların yan etkileri gibi faktörler nedeniyle hastaların iyilik halinde bozulma ve yaşam kalitesinde azalma olduğu belirlenmiştir. ${ }^{46}$

\section{Kanser Hastalarında Yaşam Kalitesi ile Din ve Maneviyat İlişkisi}

Kanser hastalarında yaşam kalitesinin amacı hastalığın getirdiği çeşitli engellemelere rağmen hastaların kendilerini mümkün olduğunca iyi hissetmelerine yardımcı olmak, günlük yaşam aktivitelerini sürdürmelerine destek olmak, fiziksel, sosyal ve psikolojik iyilik hali gibi yaşam kalitesi boyutlarında olumlu yönde gelişim sağlamaktır. ${ }^{47}$ Dolayısı ile kanserde, birden fazla bileşeni olan yaşam kalitesini etkileyen çok sayıda faktör vardır. Bunlar arasında $\mathrm{D} / \mathrm{M}$, hem bileşen hem de etkileyen olarak önemli bir faktördür.

Kanser hastalarında yaşam kalitesi ile D/M arasındaki bağın kompleks ve çok boyutlu olduğu söylenebilir. Ancak bu bağ iki yaklaşımla ele alınabilir. Birinci yaklaşımda bütüncül bakış açısı esastır. Buna göre D/M, yaşam kalitesinin tamamlayıcı bir unsuru olarak diğer unsurlarla birlikte görev yapar. İkinci yaklaşımda ise D/M, yaşam kalitesini etkileyen önemli bir diş faktör olarak ele alınıp bu iki değişken arasındaki ilişkiler ve etkileşimler bağlaminda incelenebilir.

43 Derya Kanarığ Gürel, Çukurova Üniversitesi Tıp Fakültesi Balcalı Hastanesi Erişkin Onkoloji, Hematoloji Kliniklerinde Kemoterapi Uygulanan Hastalarm Yaşam Kalitesi ve Bunu Etkileyen Faktörlerin Incelenmesi (Yüksek Lisans Tezi, Çukurova Üniversitesi, 2007), 24.

44 Özen Önen Sertöz v.dğr., "Meme Kanserinde Ameliyat Tipinin Beden Alg1sı, Cinsel İşlevler, Benlik Saygısı ve Eş Uyumuna Etkileri: Kontrollü Bir Çalışma”, Türk Psikiyatri Dergisi 15/4 (ts.): 264-275.

45 Kevser Yeter v.dğr., "Meme Kanserinde Rekonstrüktif Cerrahinin ve Hasta Eğitiminin Yaşam Kalitesine Etkisi", Meme Sağhlğg Dergisi 5/2 (2009): 65-68.

46 Mollaoğlu, "Kronik Hastalıklarda Yaşam Kalitesi ve Hemşirelik", 9.

47 Mollaoğlu, "Kronik Hastalıklarda Yaşam Kalitesi ve Hemşirelik”, 10. 
İnsanın sübjektif algılarına bağlı olan yaşam kalitesini tam olarak anlamak, onu bir bütün olarak görmekle mümkündür. Bireyin bir bütün olarak anlaş1masına yardımcı olan holistik süreç, bilişsel, duyusal ve duygusal tüm boyutların varoluşsal her türlü gözlemde aktif rol üstlendiğini kabul eder. Holizme göre bütün, kendini oluşturan parçaların toplamından daha büyüktür. ${ }^{48}$ Güncel sağlık yaklaşımları da insanın spiritual (manevi) yönünü öne çıkaran ve bütüncül (holistik) bakışı temel alan modeller üzerinde durmaktadır. (Bk. Şekil 1)

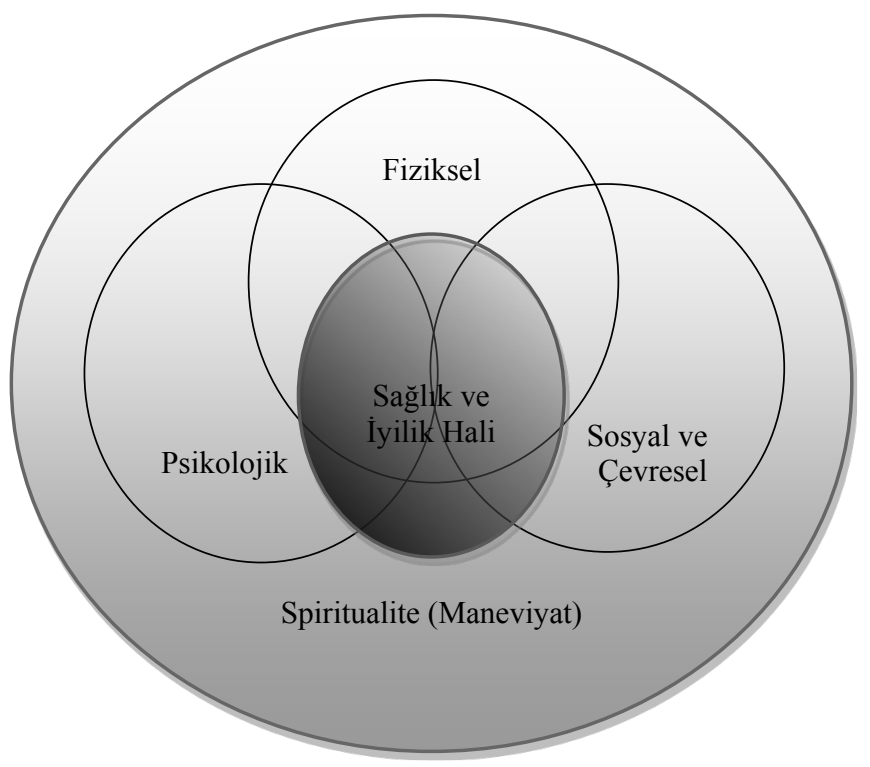

Şekil 1. Holistik Biyo-Psiko-Sosyal Sağlıkta Spiritualitenin Birlikteliği İçin Model ${ }^{49}$

Dolayısıyla varoluşsal sorgulamaları da beraberinde getiren kanser gibi önemli rahatsızlıklarda, sağlığın varoluşsal alanını anlamak da bu bütüncül (holistik) yaklaşıma bağlıdır. Dünya Sağlık Örgütü bütüncül bir yaklaşımla yaşam kalitesine ait fiziksel, psikolojik, bağımsızlık düzeyi, sosyal ilişkiler, çevresel ilişkiler ve din-spiritualite-bireysel inançlar olmak üzere altı boyut tanımlamıştır. Din-spiritualite-bireysel inançlar olarak eklenen altıncı boyutta; spiritual ilişki, hayatın anlamı ve amacı, dini-mistik tecrübe, birleşme ve bütünleşme, spiritual güç, iç huzur, umut ve iyimserlik, inanç gibi alanlara yer verilmiştir. ${ }^{50}$

48 Hatice Kurdak, "Sağlığın Varoluşsal Boyutu ve Yaşam Kalitesi", Turkiye Klinikleri Journal of Family Medicine Special Topics 5/3 (2014): 25.

49 Shirley P. Hoeman, Rehabilitation Nursing Process, Application and Outcomes 3rd Edition (St. Louis: Mosby Publication, 2002); akt. Özden Dedeli - Gülten Karadeniz, “Kanser Ağrısının Kontrolü ile Psikososyal-Spiritüel Modelin Birleștirilmesi", A $\breve{g} r$ 21/2 (2009): 45-53.

50 WHO SRPB Quality of Life Group, Scoring and Coding for the WHOQOL-SRBP Field-Test Instrument (Geneva: WHO, 2012), 2-4. 
Geliştirilen bu ve benzeri modeller yaşam kalitesinin, dini-manevi boyuttan bağımsız olamayacağını ve insana varoluşsal anlamda bütüncül olarak bakılmasının gerekliliğini göstermektedir. ${ }^{51}$ Çünkü birey, sahip olduğu inançlar ve değer sistemleri vasıtasıyla davranış ve tutumlarını belirler, kendisine nihai bir amaç edinir ve hayatı anlamlandırır.

Yaşam kalitesi boyutları, Maslow'un "ihtiyaçlar hiyerarşisi” çerçevesinde ele alındığında, alt basamakta yer alan biyolojik ve fizyolojik ihtiyaçların karşılanması, fiziksel boyut; sevgi, psikolojik boyut; ait olma ve sayg1, sosyal boyut; kendini gerçekleştirme ise manevi boyutta karşılık bulabilir. Dolayısıyla kanserde iyi bir yaşam kalitesi, bireyin alt ve üst düzey ihtiyaçlarının tatmin edilmesine bağlıdır. Böylece birey, mutlu, memnun, huzurlu, ruhsal anlamda sağlıklı, yaşam doyumuna erişmiş, yaşamın anlamını ve amacını kavramış olacaktır. Buradan hareketle "kendini gerçekleştirme" ve "yaşam doyumu"52 olarak da tanımlanan yaşam kalitesi kavramında dini-manevi boyutun daha geniş ve kapsayıcı bir anlam kazandığı ortaya çıkmaktadır.

D/M'nin yaşam kalitesine olan katkısının sağlık davranışları, sosyal destek, psikolojik durumlar ve başa çıkma mekanizmaları vasıtasıyla olduğu söylenebilir. Buna göre D/M, bedeni Allah'ın bir emaneti olarak görür ve bu konuda çeşitli sağlık davranışları (alkol vb. zararlı madde kullanımı, yeme-içmede denge vb.) ile tavsiyelerde bulunur. Ayrıca hastalık vb. durumlarda tedavi olmayı teşvik eder. Aynı zamanda D/M, güçlü bir sosyal destek ağı oluşturarak inananlara birlik ve beraberliğin, zor durumda ve sıkıntıda olanların yardımına koşmanın, hastaları ziyaret etmenin kutsallığını vurgular. ${ }^{53}$ Özellikle travmatik yaşantılarda sevgi, şefkat, merhamet, bağlılık vb. değerlerle bireye yaklaşılması, psikolojik sağlık açısından önemlidir. ${ }^{44}$ Kanser sürecinde hasta ile din kardeşlerinin kurmuş olduğu değer yönelimli ilişkiler, yaşam kalitesinin önemli bir göstergesi olan "bireysel iyilik hali"55 üzerinde olumlu yönde katkı sağlayacaktır. Bu bağlamda yapılan çalışmalar; aile, arkadaş ve çevreden gelen sosyal desteğin, ümidi azalmış kanser hastalarına umut aşılamada ve hayata karşı pozitif bakış açısı geliştirmede oldukça etkili olduğunu göstermektedir. 56

51 Kathryn A. O'Connell - Suzanne M. Skevington, “The Relevance of Spirituality, Religion and Personal Beliefs to Health-Related Quality of Life: Themes From Focus Groups in Britain", British Journal of Health Psychology 10/3 (2005): 379-398.

52 Hutchinson v.d̆gr., Health Outcome Measures in Primary and Out-Patient Care, 189.

53 Oman - Thoresen, "Din ve Maneviyat Sağlığ 1 Etkiler mi?", 304.

54 Hökelekli, Din Psikolojisine Giriş, 103.

55 Top v.dğr., "Psikiyatride Yaşam Kalitesi", 20.

56 Beser - Öz, "Kemoterapi Alan Lenfomalı Hastaların Anksiyete-Depresyon Düzeyleri ve Yaşam Kalitesi", 48. 
Olumlu ruh halinin ve pozitif duygusal durumların, organizma üzerindeki allostatik yükü azaltarak fiziksel sağlık üzerinde iyileşme sağladığı düşünülmektedir. Bunun yanında allostatik yükün (beyin ve beden üzerinde stres ve sağlıksız davranışlara bağhl olarak meydana gelen "aşınma ve yıpranma")57 azalmasının kalp-damar sistemini rahatlattığı ve bağışıklık sistemini de güçlendirdiği varsayılmaktadır. Dolayısıyla D/M, insanda pozitif duygulanıma neden olarak fiziksel ve ruhsal sağlığa olumlu yönde katkı sağlar. ${ }^{58}$ Bu yüzden fiziksel ve ruhsal sağlık karşılıklı etkileşim içindedir ve aralarında kesin bir ayrım yapmak zordur.

Kanser tanısı aldığında hastaların vermiş olduğu tepkinin; inançlara, değer sistemlerine, başa çıkma mekanizmalarına göre değiştiği belirlenmiştir. Kanser, bireyin o güne kadar yaşamını sürdürmekte ve sorunlarını çözmekte kullandığı başa çıkma mekanizmalarının ve destek sistemlerinin yeterli olmadığını fark etmesine ve bu nedenle duygusal, bilişsel ve fiziksel alanda güçsüzlük, çaresizlik, korku, kaygı ve dağılma gibi duygular yaşamasına neden olur. ${ }^{59} \mathrm{Bu}$ süreçte hastalarda dini inanç ve değer sistemleri önemli bir başvuru kaynağıdır. Dolayısı ile D/M'nin, kanser hastalarında yaşam kalitesine olan etkisi daha çok anksiyete, depresyon, belirsizlik, ümitsizlik, ölüm korkusu, varoluşsal sorunlar, anlam ve amaç arayışı gibi durumlarla olan ilişkisi bağlaminda ele alınabilir.

Yapılan çalışmalar, kanser tanısına bağlı olarak yaşanılan anksiyete ve depresyonun, hastalarda anlama ve kavrama düzeyini bozduğunu, duygularını paylaşma ve baş etme yöntemlerini kullanma becerilerini azalttığını, sosyal etkileşimde bulunma ve sosyal destek almayı zorlaştırdığını, hastalıkla mücadele gücünü azalttığını, tedaviye uyumu etkilediğini ve hastanede kalış süresini uzattığını göstermektedir. Bunlara bağlı olarak da hastalarda yaşam kalitesinin düştüğü tespit edilmiştir. ${ }^{60}$ Hastaların yaşamış olduğu belirsizliğin ise korku, öfke ve çaresizlik duygularının yaşanmasına, geleceğe yönelik kayg1lara ve ölüm korkusuna neden olduğu tespit edilmiştir. ${ }^{61}$

Kanserli hastalar için ölüm ve ölmek zorunda olduğu düşüncesinin kaç1nılmaz bir olgu olduğu kabul edilmektedir. ${ }^{62}$ Ölüm olgusu, birey için yok

57 Robert-Paul Juster v.dğr., "Elevated Allostatic Load in İndividuals Presenting At Psychiatric Emergency Services", Journal of Psychosomatic Research 115 (2018): 101-109.

58 Oman - Thoresen, “Din ve Maneviyat Sağlığı Etkiler mi?", 316.

59 Sibel Asi Karakaş, Kanser Hastalarının Hastalı̆̆ı Değerlendirme Biçimlerinin Anksiyete, Depresyon ve Yaşam Kalitesine Etkisi (Yüksek Lisans Tezi, Atatürk Üniversitesi, 2007), 13-15.

60 Ruhuşen Kutlu v.dğr., "Kanserli Hastalarda Depresyon ve Yaşam Kalitesini Etkileyen Faktörler", Selçuk Üniversitesi Tip Dergisi 27/3 (2011): 149-153.

61 Kanarı̆̆ Gürel, Çukurova Üniversitesi Tip Fakültesi Balcalı Hastanesi Erişkin Onkoloji, Hematoloji Kliniklerinde Kemoterapi Uygulanan Hastalarm Yaşam Kalitesi ve Bunu Etkileyen Faktörlerin Incelenmesi, 24.

62 Beyhan Bag, "Kanser Hastalarında Uzun Dönemde Görülen Psikososyal Sorunlar", Psikiyatride Güncel Yaklaşımlar 5/1 (2013): 109-126. 
olma tehdidi olarak algılandığında varoluşsal kaygıları da beraberinde getirir. Ölümün algılanma tarzı, bireyin inanç sistemiyle yakından ilişkilidir. Bazılarına göre ölüm bir yok oluş, bazıları için de sonsuzluğa açılan kapıdır. ${ }^{63}$

İnsani çaresizlik ile İlahi yardıma başvurma arasında önemli bir bağ olduğu düşünülmektedir. Özellikle ölüm tehlikesi, ölümle yüz yüze gelme ve hastalıklar gibi çaresizlik durumları, din duygusunun uyanmasında önemli faktörler olarak bilinmektedir. ${ }^{64}$

$\mathrm{D} / \mathrm{M}$; hayatın amacı, hedefi ve kaderin anlamı gibi kapalı konularda insanı aydınlatır ve yol gösterir. Böylece insan hastalık, ölüm gibi travmatik olayları karşısında D/M referanslar çerçevesinde yorumlamaya yönelik zihinsel kategoriler oluşturur. ${ }^{65}$ İnsan zihni, genel işleyişi itibariyle karşılaştığ 1 her olay ve nesneye bir anlam yükleyerek, psikolojik gerginliği ve belirsizliği ortadan kaldirmaya çabalar. ${ }^{66}$

İnsan, yaşamın sıradanlığına ve belirsizliğine karşı yaşamı anlamlandırma ve yaşamda amaç bulma çabası ve kaygısı içindedir. İnsan anlam ve amacını bulamadığında birçok bedensel ve ruhsal sorunlarla yüzleşmek zorunda kalır. Birey; amaçsızlık duygusunda, anksiyete, yalıtım, çaresizlik vb. durumlar yaşayabilir. Anlam yitiminde ise çeşitli nörotik bozukluklar, özkıyım eğilimi, alkol ve madde kullanımı, noojenik ya da varoluşsal nörozlar, boşluk hissi, apati (ilgisizlik, duygusuzluk), özgüven yitimi vb. sorunların yaşanabileceği bildirilmiştir. ${ }^{67}$

Kanser, varoluşsal kaygılar ve sorgulamaları ile hastaları bedensel ve ruhsal tüm boyutları ile etkilemektedir. Özellikle belirsizlik algısı, duygusal boyutta sağlığı olumsuz etkileyen bir durumdur. Hastalık yaşantısında belirsizlik algısını; bilinmeyen olaylar, tahmin edilemeyen bulgular, bilgi eksikliği, anlaşılır olmayan açıklamalar, yaşamı kontrol edememe duygusu, tedavi etkinliğinin ve hastalığın seyrinin belli olmaması gibi faktörler etkileyebilmektedir. Kanser hastalarının, hastalığın her evresinde belirsizlik yaşadığı ve bu durumun kansere özgü olduğu ifade edilmektedir. Örneğin; hastalarda tanı evresinde "acaba kanser miyim?", tedavi evresinde "iyileşebilir miyim?", tedaviden sonra "hastalığım tekrarlar mı?", terminal dönemde "ne zaman öleceğim?" gibi sorular ve düşünceler oluşabilmektedir. Belirsizliğin stres, psiko-

63 Mustafa Koç, “Ölüm Korkusu Üzerine Kuramsal Açıdan Psikolojik Bir Değerlendirme”, Sakarya Üniversitesi Illahiyat Fakültesi Dergisi 4/6 (2002): 7-22.

64 Hayati Hökelekli, Din Psikolojisi (Ankara: Diyanet Vakfı Yayınları, 2010), 90.

65 Abdülkerim Bahadır, İnsanın Anlam Arayışı ve Din, 2. Baskı (İstanbul: İnsan Yayınları, 2011), 147.

66 Bahadır, İnsanın Anlam Arayışı ve Din, 20.

67 Kurdak, "Sağlığın Varoluşsal Boyutu ve Yaşam Kalitesi", 27. 
sosyal uyum sorunları ve negatif duygu durumlarıyla doğrudan ilişkili olduğu, ümit, beklenti, amaç, baş etme becerisi ve yaşam kalitesi ile de negatif yönde ilişkili olduğu tespit edilmiştir. ${ }^{68}$

D/M, ümit duygusunun kaynağıdır. Yaşanan sıkıntının yüce bir kudrete havale edilmesi acının ve kederin hafiflemesini sağlar. ${ }^{69}$ Her şeyin kontrolünün yüce bir kudret elinde olduğunun bilinmesi, insana güven verir. "İnsan, bindiği uçağın pilotuna güvenirse huzur içinde seyahat eder. Eğer kâinatın kaptanına güvenmiyorsak huzurlu olamayız." Bütün olaylar karşısında yüce bir kudrete teslim olmak, O'nun bizim hakkımızda en iyi kararı vereceğine inanmaktır. ${ }^{70}$ Böylece, D/M vasıtasıyla belirsizlik, ümitsizlik ve çaresizlik duygularının getirmiş olduğu yıkıcı etki azalmış olur.

Literatür de bu sonucu desteklemektedir. Tanri'ya güven verici olarak bağlanmanın hayattan memnun olma, uyumluluk, ölümsüzlük gibi pozitif duyguları güçlendirdiği ayrıca fiziksel hastalık, depresyon, kaygı, yalnızlık gibi olumsuz durumları azalttığı yönünde bulgular elde edilmiştir. ${ }^{71}$

İnsan, "varoluşu çöktüğü anda, kendi akıbetine kendi kendisinin sahip olmadığını kuvvetle tecrübe etmektedir". ${ }^{72}$ Kanser tanısı ve tedavisi, bireyde "ben kimim?", "benim bugüne kadar yaşantımda oluşturduğum değerler, ilkeler neler?", "yaşam hedeflerim nelerdi?", "ben bu yaşantımın neresinde varım?", "yaşadığım bu durumun anlamı ne?" gibi varoluşsal anlamda sorgulamalara neden olur. ${ }^{73}$

Yeryüzünde anlam arayışı içinde olan tek canlı, insandır. Dolayısı ile anlam arayışı, insanın ayırt edici bir özelliğidir. ${ }^{74}$ İnsan, dünyayı anlamlı ilişkiler ağı olarak görür. Bu ağ içinde kendisini ve varlığg konumlandırır. Rutin yaşam içinde insan "yaşamın anlamı nedir?", "yaşamın amacı nedir?" gibi sorularla meşgul olmaz. Ancak hayatın akışı, insan için yoldan saptığında, çetin sinavlar, hastalıklar, acılar ve sıkıntılar baş gösterdiğinde bu sorgulamalar da başlar. ${ }^{75}$

Anlam, insanın varoluşunun özüne işaret eden derin bir kavramdır. D/M ve anlam arasındaki ilişki de bir o kadar derin ve karmaşıktır. D/M, çok sayıda insan için gerçeği idrak etme ve yorumlamada temel başvuru kaynağıdır.

68 Fatma Öz, “Hastalık Yaşantısında Belirsizlik”, Türk Psikiyatri Dergisi 12/1 (2001): 62.

69 Nevzat Tarhan, Yunus Terapi (İstanbul: Timaş Yayınları, 2013), 50.

70 Tarhan, Yunus Terapi, 59.

71 Wade C. Rowatt - Lee A. Kirkpatrick, "Two Dimensions of Attachment to God and Their Relation to Affect, Religiosity, and Personality Constructs", Journal for the Scientific Study of Religion 41/4 (2002): 637-651.

72 Hökelekli, Din Psikolojisi, 91.

73 Hallaç - Öz, "Genital Kanser Tanı Sürecinde Varoluşsal Kayg1”, 595-610.

74 Robert A. Emmons, "Striving for the Sacred: Personal Goals, Life Meaning, and Religion", Journal of Social Issues 61/4 (2005): 731-745.

75 Alfred Adler, Yaşamın Anlam ve Amacı, trc. Kamuran Şipal, 13. Baskı (İstanbul: Say Yayınları, 2017), 7-8. 
D/M'nin sağlık üzerindeki etkisi, önemli bir anlam kaynağı olması ile yakından ilişkilidir. ${ }^{76}$ Özellikle stresli ve travmatik yaşam olaylarında birey, anlam krizine girer ve sorgulamalar başlar. Özellikle dinler, 1stırap ve ölüm gibi kolay anlaşılamayan olaylar karşısında, temel bir model veya rasyonel/mantıki bir düzen ve amacın olduğuna dair hazır yanıtlar sunar. Yapılan araştırmalar, dindar insan için bu tür durumlarda, dinin merkezi bir konumda olduğunu ve seküler sistemlerle karşılaştırıldığında daha kuşatıcı ve varoluşsal boyutta daha tatmin edici bir rol oynadığını göstermektedir. ${ }^{77}$

$\mathrm{D} / \mathrm{M}$, insana inanç, umut, aşkınlık, teslimiyet, hoşgörü ve anlam aşılar. Hayat, kontrol dışına çıktığında ve yaşanan olaylar için rasyonel bir açıklama olmadığında D/M ortaya çıkar. Böylece sorgulamaların, kaos ve korkunun yerini nihai anlam, düzen ve emniyet alır. ${ }^{78}$ Frankl, bireyin aradığ 1 "anlam" 1 bulduğunda yalnızca mutluluğa ulaşmış olmayacağını aynı zamanda acıyla başa çıkabilecek yetiyi de kazanmış olacağını ifade eder. ${ }^{79}$

$\mathrm{D} / \mathrm{M}$, insanın tatminsizliğine cevap vererek, yaşadığ sındaki uyuşmazlığa çözüm yolu üretir. İnsanı güzel davranışlara ve ahlaki değerlere yönlendirerek "kendini gerçekleştirme" arzusunun önünü açar. İnsana kendi hakikatinin "ne olduğu" nun açıklamasını ve "varoluş" içinde kendini bir yere yerleştirmeye imkân veren bir başvuru çerçevesi sunar. ${ }^{80}$

Literatür, kanserle başa çıkma sürecinde D/M pratik ve uygulamaların etkili olduğunu göstermektedir. ${ }^{81} \mathrm{Bu}$ çalışmalarda, hastalarda stresin azalmasında, hastalığa ilişkin kontrol duygusunun yitirilmemesinde, benlik saygısının oluşmasında, duygusal desteğin, umudun sağlanmasında ve en önemlisi de yaşamdaki anlam ve amaca ulaşmada D/M'nin önemli rol oynadı̆̆1 tespit edilmiştir. ${ }^{82}$

Sağlık alanında D/M ile yaşam kalitesi ilişkisi üzerine yapılan diğer araştırmalar da D/M'nin; kanser gibi varoluş krizi oluşturan hastalıklarda, ruh

76 Crystal L. Park, "Din ve Anlam”, Din ve Maneviyat Psikolojisi: Yeni Yaklaşımlar ve Uygulama Alanları, ed. Raymond F. Paloutzian - Crystal L. Park, ed. İhsan Çapcıŏlu - Ali Ayten, trc. İlker Yenen (Ankara: Phoenix Yayınevi, 2013), 29.

77 Park, “Din ve Anlam”, 36-38.

78 Kenneth I. Pargament v.dğr., "The Sacred and the Search for Significance: Religion as a Unique Process", Journal of Social Issues 61/4 (2005): 665-687.

79 Viktor Emil Frankl, İnsanın Anlam Arayışı, trc. Selçuk Budak (İstanbul: Okuyan Us Yayınevi, 2012), 150-151.

80 Hökelekli, Din Psikolojisi, 96, 115-116.

81 Jason Q. Purnell - Barbara L. Andersen, "Religious Practice and Spirituality in The Psychological Adjustment of Survivors of Breast Cancer", Counseling and Values 53/3 (2009): 165-283; S C Johnson - B Spilka, “Coping With Breast Cancer: The Roles of Clergy and Faith”, Journal of Religion And Health 30/1 (1991): 21-33.

82 Ingela C. Thuné-Boyle v.dğr., “Do Religious/Spiritual Coping Strategies Affect Illness Adjustment in Patients With Cancer? A Systematic Review of The Literature", Social Science E Medicine 63/1 (2006): 151-164. 
sağlığına pozitif yönde etkileri olduğunu göstermektedir. Ayrıca manevi iyi oluşu daha fazla olan kanser hastalarının anksiyete ve depresyon düzeylerinin daha düşük, umut ve yaşam kalitelerinin ise daha yüksek olduğu yönünde bulgular vardır. ${ }^{83}$ Romero ve arkadaşlarının meme kanseri kadın hastalarda yaptıkları çalışmada; kendini affetme tutumunun ve maneviyatın, yüksek yaşam kalitesinin en iyi yordayıcıları olduğu tespit edilmiştir. ${ }^{84}$

Friedman ve arkadaşlarının yapmış olduğu başka bir araştırmada da benzer sonuçlara ulaşılmıştır. Kendini affetme ve maneviyat düzeyinin yüksek olması ile azalmış duygu-durum bozukluğu ve daha iyi yaşam kalitesi arasında anlamlı bir ilişki olduğu bildirilmiştir. ${ }^{85}$ Yale Üniversitesi'nden araştırmacıların kanser hastalarında, dini başa çıkmanın yaşam kalitesi ile ilişkisini incelediği bir diğer çalışmada da pozitif dini başa çıkmanın daha fazla kullanılmasının yüksek yaşam kalitesi ile ilişkili olduğu gösterilmiştir. ${ }^{86}$

D/M'nin; hayata bir anlam vermek, kişisel kontrol duygusunu geliştirmek ve benlik saygısını inşa etmek gibi önemli rolleri vardır. Aynı zamanda D/M, içtenlik ve kimlik, huzur ve gelişim, rahatlama ve kendini frenleme, problem çözme, umut ve ruhi fonksiyonlar gibi diğer önemli amaçlara da hizmet ederek ${ }^{87}$ bireyin yaşam doyumunda ve yaşam kalitesinin spiritual boyutu ile ilişkili olarak tüm boyutların düzeyinde gelişim sağlar.

Literatür, kanser hastalarında yaşam kalitesinin fiziksel, sosyal, psikolojik, varoluşsal/spiritüel boyutları ile D/M arasında geniş bir etkileşim ve ilişki ağı olduğunu göstermektedir. Konuyla ilgili çalışmaların bulgularından hareketle bu ağ şöyle özetlenebilir:

1. D/M (gelenek, mezhep ve gruplara göre farklılıklar olabilir) genel olarak mensuplarına bedeni ve ruhu korumaya yönelik beslenme ve sağlık davranışlarını öğütler. Alkol, uyuşturucu, sigara gibi sağlığa zarar veren alışkanlıkları yasaklar. Aynı zamanda D/M uygulama ve pratiklerin (namaz, meditasyon vb.), bedensel ve ruhsal sağlık üzerinde de olumlu etkileri vardır. ${ }^{88}$ Dolayısıyla bu teşvik ve uygulamalar, bireyin yaşam kalitesine fiziksel ve ruhsal boyutlarıyla katkı sağlar. Kanser

83 Sian P. Cotton v.dğr., "Exploring The Relationships Among Spiritual Well-Being, Quality of Life, And Psychological Adjustment in Women With Breast Cancer", Psycho-Oncology 8/5 (1999): 429-438.

84 Catherine Romero v.dğr., "Self-Forgiveness, Spirituality, and Psychological Adjustment in Women with Breast Cancer", Journal of Behavioral Medicine 29/1 (2006): 29-36.

85 Lois C. Friedman v.dğr., "Self-blame, Self-forgiveness, and Spirituality in Breast Cancer Survivors in a Public Sector Setting", Journal of Cancer Education 25/3 (2010): 343-348.

86 Tarakeshwar v.dğr., "Religious Coping is Associated with the Quality of Life of Patients with Advanced Cancer", 646-657.

87 Kenneth Pargament, “Tanrım Bana Yardım Et: Din Psikolojisi Açısından Başa Çıkmanın Teorik Çatısına Doğru", trc. Ahmet Albayrak, Tabula Rasa-Felsefe Teoloji 3/9 (2003): 219.

88 Asım Yapıcı, Ruh Sağlığı ve Din: Psiko-Sosyal Uyum ve Dindarlık (Adana: Karahan Kitabevi, 2007), 63-64; Oman - Thoresen, “Din ve Maneviyat Sağllğı Etkiler mi?", 304-305. 
hastalarında teşhis ve tedavi sonrası $\mathrm{D} / \mathrm{M}$ ile ilişkili olarak olumlu sağlık davranışlarında (tedavi alma, doğal ve sağlıklı beslenme, alkol ve sigara tüketimini azaltma veya kesme vb.) artış olduğu yönünde bulgular elde edilmiştir. Ayrıca dua, ibadet, meditasyon vb. dini ve spiritual pratiklere daha fazla yönelim olduğu belirlenmiştir. ${ }^{89}$

2. Özellikle din; sağlık ve iyilik halinde şükretmenin, her türlü s1kıntı ve hastalık halinde ise sabretmenin değerini vurgular. Hastalığın, bir imtihan ve sabır vesilesi olarak görülmesi kanser hastalarında "genel iyilik hali"ni etkileyerek yaşam kalitesine olumlu yönde katkı sağlar. 90

3. Dini/manevi bir grup içinde olmak hastalık ve sıkıntı halinde dayanışma ve yardımlaşmayı sağlayarak önemli bir sosyal destek ağ oluşturur. Özellikle kanser yaşantısında aileden ve çevreden alınan sosyal desteğin önemli olduğu, hastalıkla pozitif başa çıkma ve daha iyi bir yaşam kalitesi ile ilişkili olduğu bulunmuştur. ${ }^{91}$

4. Tanrı ya da yüce bir güç ile kurulan güvenli bağlanmanın O'na yönelmenin kanser yaşantısında stres, depresyon, anksiyete gibi psikolojik sorunlarla başa çıkmada etkili bir mekanizma oluşturduğ ${ }^{92}$ dua ve ibadetlerle O'na yakınlaşmaya çalışmanın hastaları rahatlattığı ve

89 Namratha Kandula v.dğr., “Cardiovascular Disease \& Cancer Risk Among South Asians: Impact of Sociocultural Influences on Lifestyle and Behavior", J Immigrant Minority Health 21 (2019): S15-S25; Crystal L. Park v.dğr., "Religiousness/Spirituality and Health Behaviors in Younger Adult Cancer Survivors: Does Faith Promote A Healthier Lifestyle?", J Behav Med 32 (2009): 582-591; C.1. Park v.dğr., “Different Dimensions of Religiousness/Spirituality Are Associated With Health Behaviors in Breast Cancer Survivors", Psycho-Oncology 27/10 (2018): 2466-2472; Jung- won Lim v.dğr., "Health Behavior Changes following Breast Cancer Treatment: A Qualitative Comparison among Chinese American, Korean American, and Mexican American Survivors", Journal of Health Care for the Poor and Underserved 24 (2013): 599-618.

90 Ahmet Albayrak - Emine Kurt, "Meme Kanserli Hastalarda Ağrı ve Uzuv Kaybına (Mastektomi) Bağlı Depresyon Düzeylerinin Yaşam Kalitesi ve Dindarlık ile İlişkisi", Dokuz Eylül Üniversitesi İlahiyat Fakültesi Dergisi, Din Psikolojisi Özel Sayısı (2016): 70.

91 Ellen G. Levine, "The Benefits of Prayer on Mood and Well-Being of Breast Cancer Survivors", Support Care Cancer 17/3 (2009): 295-306; Kurt, Meme Kanserli Hastalarda Ağrn ve Uzuv Kaybına (mastektomi) Bağlı Depresyon Düzeylerinin Yaşam Kalitesi ve Dindarlık ile İlişkisi, 187; Kathleen Dukes Holland - Carole K. Holahan, "The Relation of Social Support and Coping to Pozitive Adaptation to Breast Cancer", Psychology and Health 18/1 (2003): 15-30.

92 Veysi Ceylan, Meme Kanseri Olan Hastalarda Tanı Sonrası Psikososyal Sorunlar (Uzmanlık Tezi, Dicle Üniversitesi Tıp Fakültesi, 2009), 50-53; Fatemeh Haghighi, “Correlation Between Religious Coping and Depression in Cancer Patients", Psychiatria Danubina 25/3 (2013): 236-240; Emine Kurt, "Kanser Hastalarında Depresyon, Yaşam Kalitesi ve Dindarlık", Din, Değerler ve Sağlık, ed. Hayati Hökelekli (İstanbul: Dem Yayınları, 2017), 196. 
ümitsizlikten koruduğu gözlenmiştir. Ayrıca fiziksel ve ruhsal anlamda hastalık semptomları ile baş etmede önemli bir destek kaynağı olduğuna ilişkin bulgular vardır. ${ }^{93}$

5. Kanser hastalarında D/M'nin hayat, hastalık ve ölüme dair güçlü bir anlam kaynağı oluşturduğu böylece çekilen acı ve sıkıntılara dayanma ve hastalıkla mücadele etmeye yardımcı olduğu belirlenmiştir. ${ }^{94}$

\section{Sonuç}

Kanser hastalarında yaşam kalitesi, bireysel iyilik halinin öznel bir yansıması olup hastalığın ve tedavisinin hasta üzerindeki etkilerinin fiziksel, emosyonel, sosyal ve spiritüel boyutlarıyla sübjektif değerlendirmelerini içerir.

Kanser ve tedavisine bağlı semptomlar (ağrı, bulantı, halsizlik, uykusuzluk, depresyon, anksiyete vb.) hastalarda fiziksel, psikolojik, sosyal yönleriyle yaşamı kısıtlayarak yaşamdan doyum almayı engeller ve yaşam kalitesinin düşmesine neden olur. Ayrıca hastalık yaşantısına bağlı olumsuzluklar, hastaların bireysel iyilik halini bozmakta, sosyal destek almasını zorlaştırmakta, tedaviye uyumu engellemekte, hastalıkla savaşma gücünü ve baş etme becerilerini zayıflatmaktadır.

Kanser tedavisinde temel yaklaşım semptomların giderilmesi, yaşam kalitesinin düzeltilmesi ve yaşam süresinin uzatılmasıdır. Kanserde yaşam kalitesinin iyileştirilmesi tedaviye uyum ve hastalıkla mücadele edebilme açısından önemlidir. Literatür bulguları, kanser hastalarında yaşam kalitesini olumlu ya da olumsuz yönde etkileyen çok sayıda faktör olduğunu göstermektedir.

Kanser hastalarında yaşam kalitesini fiziksel, ruhsal, sosyal ve manevi yönden etkileyen faktörlerin bilinmesi yaşam kalitesinin iyileştirilmesi yönünde katkı sağlayacaktır. Multidisipliner bir alan olan kanser tedavisinde yaşam kalitesinin farklı boyutlarında, ilgili disiplinlerin de yardımıyla hastalara gerekli desteğin verilmesi daha iyi bir yaşam kalitesi için önemlidir.

Kanser; çaresizlik, belirsizlik, ölüm korkusu, ümitsizlik, anlamsızlık vb. duyguların sıkça yaşandı̆̆ı ve yaşam doyumu, umut ve beklentileri olumsuz

93 Aişe Çiftçi, Hastalıklarla başa çıkmada dini rolü: Kanser Hastaları Örneği (Yüksek Lisans Tezi, Marmara Üniversitesi 2007), 65-79; Marvin Omar Delgado-Guay v.dğr., “Spirituality, Religiosity, and Spiritual Pain Among Caregivers of Patients With Advanced Cancer", American Journal of Hospice and Palliative Medicine 30/5 (2013): 455-461.

94 Christian J. Nelson v.dğr., "Spirituality, Religion, and Depression in the Terminally Ill”, Psychosomatics 43/3 (2002): 213-220; Grace J. Kim - Leonard Goldstein, “The Effects of Religion and Spirituality on Coping Efficacy for Death and Dying", Practical Pain Management, erişim: 13 Ekim 2019, https://www.practicalpainmanagement.com/resources/hospice/effects-religionspirituality-coping-efficacy-death-dying. 
yönde etkileyen travmatik bir yaşantıdır. D/M'nin kanser yaşantısında, hastalığın anlamlandırılmasında etkin rol oynadığı böylece psikolojik gerginlik ve belirsizliğin ortadan kalkmasına yardımcı olduğu düşünülmektedir. Ayrıca dini/manevi davranış ve uygulamaların, Tanrı ile tesis edilen bağın (ilişkinin) kanser hastalarında genel iyilik hali, ruhsal sağlık ve yaşam kalitesi üzerinde olumlu etkileri olduğu belirlenmiştir.

Literatür kanser hastalarında D/M'nin inanç (düşünce), ilişki, duygu ve davranışlar ekseninde yaşam kalitesini tüm boyutları ile etkileyerek bireyin yaşamda anlam, umut, doyum, memnuniyet, mutluluk ve huzur bulmasında etkili olduğunu göstermektedir. İnsanın hayata tutunması, varoluşsal kayg1ları ile yakından ilişkilidir. Birey, sahip olduğu dini/manevi inanç ve değerleri vasıtasıyla yaşamdaki anlam ve amacı bulma çabası içindedir.

Sonuç olarak kanser hastalarında daha iyi bir yaşam kalitesi için biyolojik, psikolojik ve sosyal boyutların yanı sıra dini/spiritüel boyutun da dikkate alınması ve yaşam kalitesinin diğer boyutları ile D/M arasındaki ilişkilerin değerlendirilmesi önemlidir. Kanser tedavisi sürecinde bütüncül yaklaşım modeli çerçevesinde hastaların dini/manevi destek ve gereksinimlerinin karşılanmasının yaşam kalitesine olumlu yönde katkı sağlaması beklenmektedir. Ancak ülkemizde kanser hastalarında yaşam kalitesi ile D/M arasındaki çalışmaların kısıtlı ve az sayıda olması nedeniyle bu konuda daha kapsamlı ve çok yönlü çalışmalara ihtiyaç vardır.

\section{Kaynakça}

Adler, Alfred. Yaşamın Anlam ve Amacı. Trc. Kamuran Şipal. 13. Baskı. İstanbul: Say Yayınları, 2017.

Afşar, Füsun. “Sandalye Masajı Kanserli Hastalara Bakım Veren Aile Üyelerinin Yaşam Kalitesine Katkı Verebilir mi?" 3. Ulusal Sağlıkta Yaşam Kalitesi Kongresi Bildiri ve Sunum Kitabı. İzmir: SAYKAD, 2010.

Akyol, Asiye. "Yaşam Kalitesinin Hemşirelik Yönünden Önemi". Ege Üniversitesi Hemşirelik Yüksekokulu Dergisi 9/3 (1993): 71-75.

Albayrak, Ahmet - Kurt, Emine. “Meme Kanserli Hastalarda Ağrı ve Uzuv Kaybına (Mastektomi) Bağlı Depresyon Düzeylerinin Yaşam Kalitesi ve Dindarlık ile İlişkisi”. Dokuz Eylül Üniversitesi İlahiyat Fakültesi Dergisi. Din Psikolojisi Özel Sayıs1 (2016): 41-81. https://doi.org/10.21054/deuifd.282804

Arslan, Sevban - Bölükbaş, Nurgül. "Kanserli Hastalarda Yaşam Kalitesinin Değerlendirilmesi". Atatürk Üniversitesi Hemşirelik Yüksekokulu Dergisi 6/3 (2003): 38-47.

Arslan, Şule - Kutsal, Yeşim Gökçe. "Geriatride Yaşam Kalitesinin Değerlendirimi”. Geriatri 2/4 (1999): 173-178.

Asi Karakaş, Sibel. Kanser Hastalarının Hastalı̆̆ı Değerlendirme Biçimlerinin Anksiyete, Depresyon ve Yaşam Kalitesine Etkisi. Yüksek Lisans Tezi, Atatürk Üniversitesi, 2007. 
Bag, Beyhan. "Kanser Hastalarında Uzun Dönemde Görülen Psikososyal Sorunlar". Psikiyatride Güncel Yaklaşımlar 5/1 (2013): 109-126.

https://doi.org/10.5455/cap.20130508

Bahadır, Abdülkerim. İnsanın Anlam Arayışı ve Din. 2. Baskı. İstanbul: İnsan Yayınları, 2011.

Balboni, Tracy A. - Vanderwerker, Lauren C. - Block, Susan D. - Paulk, M. Elizabeth Lathan, Christopher S. - Peteet, John R. - Prigerson, Holly G. “Religiousness and Spiritual Support Among Advanced Cancer Patients and Associations With End-of-Life Treatment Preferences and Quality of Life". Journal of Clinical Oncology 25/5 (2007): 555-560. https://doi.org/10.1200/JCO.2006.07.9046

Beser, Nalan G. - Öz, Fatma. "Kemoterapi Alan Lenfomalı Hastaların Anksiyete-Depresyon Düzeyleri ve Yaşam Kalitesi”. Cumhuriyet Üniversitesi Hemşirelik Yüksekokulu Dergisi 7/1 (2003): 47-58.

Boztilki, Melike - Ardıç, Elif. "Maneviyat ve Sağlık". Journal of Academic Research in Nursing. Ek Sayı (2017): 39-45. https://doi.org/10.5222/jaren.2017.1008

Büssing, Arndt - Koenig, Harold G. "Spiritual Needs of Patients with Chronic Diseases". Religions 1/1 (2010): 18-27. https://doi.org/10.3390/rel1010018

Campbell, Angus - Converse, Philip E. - Rodgers, Willard L. The Quality of American Life: Perceptions, Evaluations, and Satisfactions. 1st US-1st Printing edition. New York: Russell Sage Foundation, 1976.

Cella, David. “Quality of Life: The Concept". Journal of Palliative Care 8/13 (1992): 8-13.

Ceylan, Veysi. Meme Kanseri Olan Hastalarda Tanı Sonrası Psikososyal Sorunlar. Uzmanlık Tezi, Dicle Üniversitesi Tıp Fakültesi, 2009.

Cotton, Sian P. - Levine, Ellen G. - Fitzpatrick, Cory M. - Dold, Kristin H. - Targ, Elisabeth. "Exploring The Relationships Among Spiritual Well-Being, Quality of Life, And Psychological Adjustment in Women With Breast Cancer ". PsychoOncology 8/5 (1999): 429-438.

Çiftçi, Aişe. Hastalıklarla başa çıkmada dini rolü: Kanser Hastaları Örneği. Yüksek Lisans Tezi, Marmara Üniversitesi, 2007.

Dedeli, Özden - Karadeniz, Gülten. “Kanser Ağrısının Kontrolü ile Psikososyal-Spiritüel Modelin Birleştirilmesi". A ̆ğr 21/2 (2009): 45-53.

Delgado-Guay, Marvin Omar - Parsons, Henrique A. - Hui, David - Cruz, Maxine G. De la - Thorney, Steven - Bruera, Eduardo. "Spirituality, Religiosity, and Spiritual Pain Among Caregivers of Patients With Advanced Cancer". American Journal of Hospice and Palliative Medicine ${ }^{\circledR}$ 30/5 (2013): 455-461. https://doi.org/10.1177/1049909112458030

Edisan, Zehra - Kadıŏlu, Funda. "Yaşam Kalitesi Kavramının Antik Dönemdeki Öncülleri". Lokman Hekim Journal 3/3 (2013): 1-4.

Elliott, Thomas E - Renier, Colleen M - Palcher, Jeanette A. “Chronic pain, depression, and quality of life: correlations and predictive value of the SF-36 Chronic Pain, Depression, and Quality of Life: Correlations And Predictive Value of The SF36". Pain Medicine (Malden, Mass.) 4/4 (2003): 331-339.

Emmons, Robert A. "Striving for the Sacred: Personal Goals, Life Meaning, and Religion". Journal of Social Issues 61/4 (2005): 731-745.

Frankl, Viktor Emil. İnsanın Anlam Arayışı. Trc. Selçuk Budak. İstanbul: Okuyan Us Yayın, 2012. 
Friedman, Lois C. - Barber, Catherine R. - Chang, Jenny - Tham, Yee Lu - Kalidas, Mamta - Rimawi, Mothaffar F. - Dulay, Mario F. - Elledge, Richard. "Self-Blame, Self-Forgiveness, and Spirituality in Breast Cancer Survivors in a Public Sector Setting". Journal of Cancer Education 25/3 (2010): 343-348. https://doi.org/10.1007/s13187-010-0048-3

Görgün-Baran, Aylin. "Yaşlılıkta sosyalizasyon ve yaşam kalitesi". Yaşlı Sorunları Araştırma Dergisi 2 (2008): 86-97.

Haes, JC de - Knippenherg, FCE. “The Quality of Life and Survival: The Role of Multidimensionel Symptom Assessment". Cancer 83 (1993): 173-179.

Haghighi, Fatemeh. "Correlation Between Religious Coping and Depression in Cancer Patients". Psychiatria Danubina 25/3 (2013): 236-240.

Hallaç, Saliha - Öz, Fatma. "Genital Kanser Tanı Sürecinde Varoluşsal Kaygı”. Psikiyatride Güncel Yaklaşımlar 3/4 (2011): 595-610.

Hoeman, Shirley P. Rehabilitation Nursing Process, Application and Outcomes 3rd Edition. St. Louis: Mosby Publication, 2002.

Hoff, Andreas - Johannessen-Henry, Christine Tind - Ross, Lone - Hvidt, Niels Christian - Johansen, Christoffer. "Religion and Reduced Cancer Risk - What Is the Explanation? A Review". European Journal of Cancer 44/17 (2008): 2573-2579. https://doi.org/10.1016/j.ejca.2008.08.001

Holland, Kathleen Dukes - Holahan, Carole K. "The Relation of Social Support and Coping to Pozitive Adaptation to Breast Cancer". Psychology and Health 18/1 (2003): 15-30.

Hökelekli, Hayati. Din Psikolojisi. Ankara: Diyanet Vakfı Yayınları, 2010.

Hökelekli, Hayati. Din Psikolojisine Giriş. İstanbul: Dem Yayınları, 2010.

Hörnquist, J. O. "Quality of Life: Concept and Assessment". Scandinavian Journal of Social Medicine 18/1 (1990): 69-79.

Hutchinson, A. - McColi, E. - Riccalton, C. - Chiristie, Margaret. Health Outcome Measures in Primary and Out-Patient Care. Amsterdam: Harwood Academic Publishers, 1996.

Johnson, S C - Spilka, B. “Coping With Breast Cancer: The Roles of Clergy and Faith”. Journal of Religion And Health 30/1 (1991): 21-33. https://doi.org/10.1007/BF00986676

Juster, Robert-Paul - Sasseville, Marc - Giguère, Charles-Édouard - Consortium, Signature - Lupien, Sonia J. “Elevated Allostatic Load in Individuals Presenting at Psychiatric Emergency Services". Journal of Psychosomatic Research 115 (2018): 101-109. https://doi.org/10.1016/j.jpsychores.2018.10.012

Kanarı̆̆ Gürel, Derya. Çukurova Üniversitesi Tıp Fakültesi Balcalı Hastanesi Erişkin Onkoloji, Hematoloji Kliniklerinde Kemoterapi Uygulanan Hastaların Yaşam Kalitesi ve Bunu Etkileyen Faktörlerin İncelenmesi. Yüksek Lisans Tezi, Çukurova Üniversitesi, 2007.

Kandula, Namratha - Ahmed, Munerah - Dodani, Sunita - Gupta, Leena - Hore, Paromita. "Cardiovascular Disease \& Cancer Risk Among South Asians: Impact of Sociocultural Influences on Lifestyle and Behavior". J Immigrant Minority Health 21 (2019): 15-25. https://doi.org/10.1007/s10903-017-0578-4 
Kim, Grace J. - Goldstein, Leonard. "The Effects of Religion and Spirituality on Coping Efficacy for Death and Dying". Practical Pain Management. Erişim: 13 Ekim 2019. https://www.practicalpainmanagement.com/resources/hospice/effects-religion-spirituality-coping-efficacy-death-dying

Koç, Mustafa. “Ölüm Korkusu Üzerine Kuramsal Açıdan Psikolojik Bir Değerlendirme". Sakarya Üniversitesi Illahiyat Fakültesi Dergisi 4/6 (2002): 7-22.

Koenig, Harold G. "Religion, spirituality, and Health: a Review and Update". Advances In Mind-Body Medicine 29/3 (2015): 19-26.

Kurdak, Hatice. "Sağlığın Varoluşsal Boyutu ve Yaşam Kalitesi". Turkiye Klinikleri Journal of Family Medicine Special Topics 5/3 (2014): 23-28.

Kurt, Emine. "Kanser Hastalarında Depresyon, Yaşam Kalitesi ve Dindarlık". Din, Değerler ve Să̆glk. Ed. Hayati Hökelekli. 171-208. İstanbul: Dem Yayınları, 2017.

Kurt, Emine. Meme Kanserli Hastalarda Ağrı ve Uzuv Kaybına (mastektomi) Bağlı Depresyon Düzeylerinin Yaşam Kalitesi ve Dindarlık ile İlişkisi. Yüksek Lisans Tezi, Uludağ Üniversitesi, 2015.

Kutlu, Ruhuşen - Çivi, Selma - Börüban, Melih Cem - Demir, Ayşe. "Kanserli Hastalarda Depresyon ve Yaşam Kalitesini Etkileyen Faktörler". Selçuk Üniversitesi Tip Dergisi 27/3 (2011): 149-153.

Kuzeyli Yıldırım, Yasemin - Uyar, Meltem - Fadıllığlu, Çiçek. "Kanser Ağrısı ve Yaşam Kalitesine Etkisi". A $\breve{g} r ı$ 17/4 (2005): 17-22.

Levine, Ellen G. "The Benefits of Prayer on Mood and Well-Being of Breast Cancer Survivors". Support Care Cancer 17/3 (2009): 295-306.

Lewis, F. M. “Experienced Personal Control and Quality of Life in Late-Stage Cancer Patients". Nursing Research 31/2 (1982): 113-119.

Lim, Jung- won - Gonzales, Patricia - Wang- Letzkus, Ming F. - Baik, Okmi - AshingGiwa, Kimlin T. “Health Behavior Changes following Breast Cancer Treatment: A Qualitative Comparison among Chinese American, Korean American, and Mexican American Survivors". Journal of Health Care for the Poor and Underserved 24 (2013): 599-618.

Long, P. H. “On the Quantity and Quality of Life”. Medieval Times 88 (1960): 613-619.

Melson, F. Gail. Family and Environment: An Ecosystem Perspektive. Minneapolis: Burgess, 1980.

Mollaoğlu, Mukadder. "Kronik Hastalıklarda Yaşam Kalitesi ve Hemşirelik". 2. Să̆lıkta Yaşam Kalitesi Kongresi Kongre Özet Kitabı. İzmir: Meta Basım, 2007.

Müezzinoğlu, Talha. “Yaşam Kalitesi". Üroonkoloji Bülteni. 1 (2005): 25-29.

Nelson, Christian J. - Rosenfeld, Barry - Breitbart, William - Galietta, Michele. "Spirituality, Religion, and Depression in the Terminally Ill". Psychosomatics 43/3 (2002): 213-220. https://doi.org/10.1176/appi.psy.43.3.213

O'Connell, Kathryn A. - Skevington, Suzanne M. “The Relevance of Spirituality, Religion and Personal Beliefs to Health-Related Quality of Life: Themes From Focus Groups in Britain". British Journal of Health Psychology 10/3 (2005): 379-398.

Oktik, Nurgün - Bozyer, Ünal. Huzurevinde Yaşam ve Yaşam Kalitesi: Muğla Örneği. Muğla: Muğla Üniversitesi, 2004. 
Oman, Doug - Thoresen, Carl E. “Din ve Maneviyat Sağllğ viyat Psikolojisi: Yeni Yaklaşımlar ve Uygulama Alanları. Ed.Raymond F. Paloutzian - Crystal L. Park. Ed. İhsan Çapcioğlu - Ali Ayten, trc. Özer Çetin. Ankara: Phoenix Yayınevi, 2013.

Organization, World Health. "WHOQOL-SRPB: Scoring and Coding for the WHOQOL SRPB Field-Test Insturment: Users Manual". 2002. https://apps.who.int/iris/handle/10665/77778

Öz, Fatma. "Hastalık Yaşantısında Belirsizlik". Türk Psikiyatri Dergisi 12/1 (2001): 6168.

Özmete, Emine. “Aile Yaşam Kalitesi Dinamikleri: Aile İletişimi, Ebeveyn Sorumlulukları, Duygusal Refah, Fiziksel/Materyal Refahın Algılanması". Uluslararası Sosyal Araştırmalar Dergisi 3/11 (2010): 455-465.

Padilla, G. V. - Ferrell, B. - Grant, M. M. - Rhiner, M. “Defining the Content Domain of Quality of Life for Cancer Patients with Pain". Cancer Nursing 13/2 (1990): 108115.

Padilla, G. V. - Grant, M. M. - Ferrell, B. "Nursing Research into Quality of Life". Quality of Life Research 1/5 (1992): 341-348.

Pargament, Kenneth. “Tanrım Bana Yardım Et: Din Psikolojisi Açısından Başa Çıkmanın Teorik Çatısına Doğru". Trc. Ahmet Albayrak. Tabula Rasa-Felsefe Teoloji 3/9 (2003): 207-238.

Pargament, Kenneth I. - Magyar-Russell, Gina M. - Murray-Swank, Nichole A. "The Sacred and the Search for Significance: Religion as a Unique Process". Journal of Social Issues 61/4 (2005): 665-687.

Park, C.1. - Waddington, E. - Abraham, R. “Different Dimensions of Religiousness/Spirituality Are Associated with Health Behaviors in Breast Cancer Survivors". Psycho-Oncology 27/10 (2018): 2466-2472. https://doi.org/10.1002/pon.4852

Park, Crystal L. “Din ve Anlam”. Din ve Maneviyat Psikolojisi: Yeni Yaklaşımlar ve Uygulama Alanları. Ed. Raymond F. Paloutzian - Crystal L. Park. Ed. İhsan Çapcıoğlu - Ali Ayten. Trc. İlker Yenen. Ankara: Phoenix Yayınevi, 2013.

Park, Crystal L. - Edmondson, Donald - Hale-Smith, Amy - Blank, Thomas O. "Religiousness/Spirituality and Health Behaviors in Younger Adult Cancer Survivors: Does Faith Promote A Healthier Lifestyle?". J Behav Med 32 (2009): 582-591. https://doi.org/10.1007/s10865-009-9223-6

Park, Crystal L. - Masters, Kevin S. - Salsman, John M. - Wachholtz, Amy - Clements, Andrea D. - Salmoirago-Blotcher, Elena - Trevino, Kelly - Wischenka, Danielle M. "Advancing our understanding of religion and spirituality in the context of behavioral medicine". Journal of Behavioral Medicine 40/1 (2017): 39-51. https://doi.org/10.1007/s10865-016-9755-5

Patrick, D. L. - Erichson, P. Health Status and Health Policy. New York: Oxford University Press, 1993.

Perim, Aysun. Trakya Üniversitesi Ĕ̆itim, Araştırma ve Uygulama Hastanesi'nde Çalışan Hemşirelerin Kaliteli Yaşam Algısının Belirlenmesi. Yüksek Lisans Tezi, Trakya Üniversitesi, 2007.

Purnell, Jason Q. - Andersen, Barbara L. "Religious Practice and Spirituality in The Psychological Adjustment of Survivors of Breast Cancer". Counseling and Values 53/3 (2009): 165-283. 
Romero, Catherine - Friedman, Lois C. - Kalidas, Mamta - Elledge, Richard - Chang, Jenny - Liscum, Kathleen. "Self-Forgiveness, Spirituality, and Psychological Adjustment in Women with Breast Cancer". Journal of Behavioral Medicine 29/1 (2006): 29-36. https://doi.org/10.1007/s10865-005-9038-z

Rowatt, Wade C. - Kirkpatrick, Lee A. "Two Dimensions of Attachment to God and Their Relation to Affect, Religiosity, and Personality Constructs". Journal for the Scientific Study of Religion 41/4 (2002): 637-651.

Sertöz, Özen Önen - Mete, Hayriye Elbi - Noyan, Ayşın - Alper, Mehmet - Kapkaç, Murat. "Meme Kanserinde Ameliyat Tipinin Beden Alg1sı, Cinsel İşlevler, Benlik Saygısı ve Eş Uyumuna Etkileri: Kontrollü Bir Çalışma". Türk Psikiyatri Dergisi 15/4 (ts.): 264-275.

Tarakeshwar, Nalini - Vanderwerker, Lauren C. - Paulk, Elizabeth - Pearce, Michelle J. - Kasl, Stanislav V. - Prigerson, Holly G. "Religious Coping is Associated with the Quality of Life of Patients with Advanced Cancer". Journal of Palliative Medicine 9/3 (2006): 646-657. https://doi.org/10.1089/jpm.2006.9.646

Tarhan, Nevzat. Yunus Terapi. İstanbul: Timaş Yayınları, 2013.

Thuné-Boyle, Ingela C. - Stygall, Jan A. - Keshtgar, Mohammed R. - Newman, Stanton P. “Do Religious/Spiritual Coping Strategies Affect Illness Adjustment in Patients With Cancer? A Systematic Review of The Literature". Social Science E Medicine 63/1 (2006): 151-164. https://doi.org/10.1016/j.socscimed.2005.11.055

Top, Mehmet Şerif - Özden, Salih Yaşar - Efe Sevim, Meltem. "Psikiyatride Yaşam Kalitesi". Düşünen Adam 16/1 (2003): 18-23.

Türkiye Kanser İstatistikleri. Ankara: T. C. Sağlık Bakanlığı Türkiye Halk Sağlığı Kurumu, 2017.

Unantenne, Nalika - Warren, Narelle - Canaway, Rachel - Manderson, Lenore. "The Strength to Cope: Spirituality and Faith in Chronic Disease". Journal of Religion and Health 52/4 (2013): 1147. https://doi.org/10.1007/s10943-011-9554-9

University of Toronto. "Quality of Life Research Unit: home page". Erişim: 26 Haziran 2018. http://sites.utoronto.ca/qol/qol model.htm

Ünsal, Diclehan - Aksu, Atınç - Bağriaçik, Ümit - Akmansu, Müge. “Postmastektomi Radyoterapi Uygulanan Meme Kanserli Olgularda Gelişen Yorgunluğun Derecesi, Serum Sitokin ve Leptin Düzeyleri ile İlişkisi: Prospektif Değerlendirme". Türk Onkoloji Dergisi 22/1 (2007): 1-12.

WHO. "Cancer Today". Erişim: 26 Haziran 2018. http://gco.iarc.fr/today/home

WHO. "The Constitution of the WHO". WHO Chronicle, 1947.

WHO. "WHOQOL: Measuring Quality of Life". 1997. http://www.who.int/healthinfo/survey/whoqol-qualityoflife/en/

WHO SRPB Quality of Life Group. Scoring and Coding for the WHOQOL-SRBP FieldTest Instrument. Geneva: WHO, 2012.

Yapıcı, Asım. Ruh Sağlığı ve Din: Psiko-Sosyal Uyum ve Dindarlık. Adana: Karahan Kitabevi, 2007.

Yeter, Kevser - Savcı, Ayşegül - Sayıner, Fatma Deniz. "Meme Kanserinde Rekonstrüktif Cerrahinin ve Hasta Eğitiminin Yaşam Kalitesine Etkisi". Meme Sağhı̆̆ Dergisi 5/2 (2009): 65-68. 
Zinnbauer, Brian J - Pargament, Kenneth. "Dindarlık ve Maneviyat". Din ve Maneviyat Psikolojisi: Temel Yaklaşımlar ve Illgi Alanları. Ed. Raymond F. Paloutzian - Crystal L. Park. 61-102. Ed. İhsan Çapcıŏlu - Ali Ayten. Trc. Sevdenur Düzgüner. Ankara: Phoenix Yayınevi, 2013.

Zwingmann, Christian - Müller, C. - Körber, J. - Murken, S. “Religious Commitment, Religious Coping and Anxiety: A Study in German Patients with Breast Cancer". European Journal of Cancer Care 17 (2008): 361-367. https://doi.org/10.1111/j.1365-2354.2007.00867.x 


\section{Theoretical Approaches on Religion and Spirituality Affecting the Quality of Life in the Cancer Patients}

\section{(Extended Abstract)}

Today's one of the most important health problems are cancer, death and severe pain that bring about existential crisis and interrogations. Cancer treatment is long-lasting and has many side effects. Disease experience and treatment-related problems affect the quality of life by decreasing physical performance and daily living activities of the patients.

Quality of life (QL) has been discussed and interpreted within the framework of concepts such as happiness, the meaning of life, feeling good, living comfortably, living purpose, living chance and value of life by affecting medical thoughts and actions from past to present. QL in health is generally evaluated in physical, psychological and social dimensions. However, the studies have shown that the concept is much more complex and the areas of interaction are wider.

“WHO defines QL as individuals' perception of their position in life in the culture's context and value systems in which they live and concerning their goals, expectations, standards and concerns". Therefore, QL is seen as a comprehensive concept which is affected by the physical health, psychological status, independence/freedom level, social relations, individual beliefs and environmental relations of the individual.

Cancer patients, on the one hand, are dealing with the physical and mental symptoms of the disease, on the other hand, are trying to continue the activities of daily living. Because cancer patients are trying to cope with the physical and mental symptoms of the disease, they are trying to maintain their daily activities. Patients experience restrictions in many areas of life, such as family, social life, education, work, and occupational life. Therefore, the QL in cancer; physical, spiritual, social, emotional, spiritual, etc. is evaluated in many sizes. But the areas of quality of life are not independent of each other and they are in mutual relation. For example, it is known that long-term treatment and continuation of treatment-related negativities lead to uncertainty and hopelessness, and lead to pessimism, anxiety and depression. In particular, cancer therapies that affect all systems such as chemotherapy and have adverse effects that make the daily life of the individual difficult to have a significant effect on the QL.

Recent studies show that religion and spirituality is an important factor that positively affects the QL in cancer patients. However, it can be said that the relationship between QL and religion and spirituality is complex and multidimensional in cancer patients. This relationship can be treated with two approaches: In the first approach, a holistic perspective is essential. According 
to this, religion and spirituality work with other elements as a complementary element of QL. In the second approach, religion and spirituality can be considered as an important external factor affecting the quality of life and can be examined in the context of the relationships and interactions between these two variables.

It can be said that the contribution of religion and spirituality to QL is through health behaviors, social support, psychological conditions, and coping mechanisms. According to this, religion sees the body as a trust of God and makes various health behaviors (use of harmful substances such as alcohol, balance in eating and drinking, etc.). It leads to treatment in the disease. At the same time, religion emphasizes the importance of unity and cohesion to help believers and those who are in trouble and visit patients, creating a strong social support network. The literature findings also show that social support from family, friends and the environment is very effective in raising hope for patients with reduced cancer and developing a positive perspective against life.

The literature shows that religion and spiritual practices and experiences are effective in coping with cancer. In these studies, it has been determined that religion and spirituality play an important role in decreasing the stress in patients, not losing the sense of control related to the disease, creating selfesteem, providing emotional support, hope and most importantly reaching the meaning and purpose in life.

As a result, it is important to consider the biological, psychological, social dimensions as well as the religion and spirituality dimension and to evaluate the relationship between the other dimensions of QL and religion and spirituality for a better QL in cancer patients. In the process of cancer treatment, it is hoped that within the framework of a holistic approach model, meeting the religion and spirituality support and needs of the patients will contribute positively to the QL. However, there is a need for more comprehensive and multifaceted studies on QL in cancer patients and the limited number of studies between religion and spirituality. 